ISSN 2227-7242. Антропологічні виміри філософських досліджень. 2012. Вип. 1.

\title{
УДК 141.33
}

Шабанова Ю. А., ГВУЗ «Национальный горный университет» (Днепропетровск)

\section{ФИЛОСОФСКАЯ МИСТИКА В ПРОСТРАНСТВЕ ЗАПАДНОЕВРОПЕЙСКОЙ ФИЛОСОФИИ}

Исследуется феномен философской мистики, выявляется её концептуальне особенности и роль в становлении европейской историко-философской континуальности.

Ключевые слова: философская мистика, европейская философия.

Шабанова Ю. О., ДВНЗ «Національний гірничий університет» (Дніпропетровськ)

\section{ФІЛОСОФСЬКА МІСТИКА В ПРОСТОРІ ЗАХІДНОСВРОПЕЙСЬКОЇ ФІЛОСОФІї}

Досліджується феномен філософської містики, виявляється їі концептуальні особливості та роль в становленні європейської історико-філософської континуальності.

Ключові слова: філософська містика, західноєвропейська філософія.

\author{
Shabanova J. A., National Mining University (Dnipropetrovsk)
}

\section{PHILOSOPHICAL MYSTICA IN SPACE OF THE WEST-EUROPEAN PHILOSOPHY}

In article the phenomenon of philosophical mysticism is investigated, comes to light its conceptual features and a role in becoming European historico-philosophical a continuum.

Key words : philosophical mysticism, the European philosophy.

Целью данного исследования является выявление сущности философской мистики, её особенностей и форм проявления в философском контексте, что представляется актуальным в связи с искажениями и спекуляциями этого вида духовного опыта человека. Засилье СМИ примитивными и искажёнными интерпретациями мистического, отсутствие концептуальных определений мистики как в среде обывателя, так и в научных кругах влияет на формирования спекулятивных искажений в среде обывателя и как следствие превращается в форму манипуляции сознания. Философское осмысление феномена мистики призвано внести как в научный оборот, так и в сферу обыденной

(C) Шабанова Ю. А., 2012 жизни актуализированное понимание мистики, что и обусловило объект исследования в виде феномена философской мистики и его предмет в виде выявления роли философской мистики в становлении западноевропейской историкофилософской континуальности.

Определение сути мистики, в большей степени идентифицируемой с религиозным опытом, усложняется в связи с обращением к философским учениями, для которых свойственно логико-системное изложение и рациональнотеоретические формы мышления. В этой связи, необходимо внести методологическую ясность в определении философской мистики, путем разъяснения понятий мистика и мистицизм, а также выявить мистический модус в метафизике как классическом поле философии. 
ISSN 2227-7242. Антропологічні виміри філософських досліджень. 2012. Вип. 1.

Само понятие «мистика» имеет несколько толкований. Под мистическим часто понимают нечто отрицательное, темное, колдовское. Даже среди современных философских представлений существует предубеждение относительно мистического опыта.

Так, в большинстве энциклопедических изданий толкования понятия мистика подразделяются на несколько групп:

- совокупность явлений или действий, которые оказывают содействие в связи человека с тайными существами или силами (египетские или элевсинские мистерии, другие эзотерические ритуалы, культовые обряды);

- разные формы оккультизма, такие как: магнетизм, магия, теургия, медиумистические или спиритические явления;

- учение о внутреннем единении человеческого духа с абсолютным Духом как адекватное познание онтологической первоосновы мира через индивидуальный опыт духовного самопознания.

Необходимо отметить, что первое определение мистики как совокупность ритуальнокультовых действий связано с архаическими культурами (Египта, Греции, Месопотамии, и т. п.), для которых характерно мифологическое сознания. Через архаические мистерии передавались эзотерические знания о духовном мире иерофантам. Оргиастичные культуры имели цель снятия в момент ритуального действия границы между профанным и сакральным миром. «Мистика, - как указывает философский энциклопедический словарь, - первоначально была названием для тайных религий или тайных религиозных организаций, в которые принимались и посвящались только избранные»[1]. На этом этапе возникает понятие «мистический» - тайный, то есть сакральный мир за пределами профанного.

Что касается второго определения мистики, связанного со спиритическими и магическими явлениями, то оно требует четкой дифференциации от магии, оккультных наук и от философской мистики. Хотя разнообразные формы магии в своей основе содержат технику проникновения в тайный надприродный мир, по своим целям они кардинально отличаются от мистики.
Принципиальное различие между магией и мистикой заключается в их конечной цели, а именно, магия стремиться получить знания о духовном мире с целью прагматичного их применения. Мистика же через апофатизм отказывается от какого бы то ни было прагматизма, стремясь «бесцельно» преодолеть субъектобъектное разделение. «Мистика отрицает магию, прямо ей противоположна. Бог для мистиков - Великая тайна, в то время как оккультные науки тайну материализуют, «добывая» Бога алхимическим путем», - пишет Н. О. Гучинская [2].

И магия, и мистика используют механизмы как сознательной, так и бессознательной деятельности в достижении своих целей. Но цель мистики -единение через самоотдачу с трансцендентным Абсолютом. Цель магии - получить знания о трансцендентном для прагматического их использования. При этом воля в магических актах всегда объединяется с рассудком, рационально отбирающем прагматические знания. Если мистика стремится к преодолению индивидуального, то все разновидности магии всегда индивидуалистичны, ибо результаты магических действий направлены на корысть индивида или группы таковых. В этой связи второе определение мистики не входит в сферу данного исследования. Считаем необходимым исключить из аналитического массива данной работы сугубо-обывательское представление о мистике, как о чем-то необъяснимом, загадочном, странном, потустороннем, куда включаются до конца не осмысленные и, как следствие, искаженные понятия экстрасенсорики, левитации, телепортации, а также все «чудеса», связанные с мистическим невежеством (недостатком знаний для объяснения чего-то непонятного).

Таким образом, методологической основой исследования является определение понятия мистики в виде акта единения универсальной сущности трансцендентной реальности и субъекта созерцания путем расширения сознания индивидуального «Я» до абсолютного Духа, а также мистицизма, в виде максимально адекватного выражения содержания мистического опыта (духовной эмпирии) в системном оформлении определенных учений. 
ISSN 2227-7242. Антропологічні виміри філософських досліджень. 2012. Вип. 1.

В этой связи философская мистика представляется учением, органично взаимосвязанным с богатым опытом философской рефлексии, изложенном дискурсивно.

Философская мистика - это метафизический дискурс о мистическом, как трансцендентной реальности, формирующей онтогносеологические и антропо-аксиологические представления. Так, понятие «философской мистики» дистанцируется от понимания мистики, в ее культово-ритуальных проявлениях, различных формах оккультизма, примитивнообывательских представлениях (все необъяснимое, загадочное, странное, потусторонне, как результат низко-культурного уровня развития и примитивного невежества).

Выделяя философскую мистику как отдельное направление историко-философского континуума Западной Европы, следует подчеркнуть определенные закономерности ее проявлений:

- философская мистика возникает в периоды кризиса рационализма как восполняющий целостность модус метафизики;

- философская мистика переживает свой расцвет на стыке культурных эпох, мировоззренческих парадигм, смены социальных формаций;

- философская мистика несет в себе протоидеи будущих мировоззренческих парадигм, культурных ценностей;

- философская мистика способствует оформлению эволюционных рефлексивных тенденций, реализуя эвристическую функцию философии;

- философская мистика, опираясь на духовную природу Абсолюта (теистического или нетеистического толка), предвосхищает аксиологические приоритеты будущих мировоззренческих ориентиров.

Если Аристотель подводит своеобразный итог развитию греческой философии в ее логико-рациональной системности, то поиски мудрецов Эллады приводят к высшему божественному началу нерационалистического характера, развивая идею примата духовных ценностей. На этой волне античный неоплатонизм как философско-мистическое учение, провозглашает иррациональную природу Единого, утверждая «путь падения души» как путь достижения мистического состояния в виде цели человеческой жизни, где душа человека, растворяясь в абсолюте, поднимается над телесным. Так философская мистика неоплатонизма выводит понятие абсолюта за границы рационального познания, позиционируя Единое вне каких-либо акциденций. Формируя экстатический путь постижения Единого, неоплатоники лишают рациональный метод познания абсолютизации и допускают возможность субъект-объектного единения. При этом сформированная неоплатониками иерархия восхождения к Единому открывает возможность соединения идеального и чувственного мира. Такие кардинальные изменения в онтологии, которая стремясь преодолеть космологизм, содержит в себе протоидеи теоцентризма, а также в гносеологии, противопоставляющей процессу рациональноумозрительного познания акт экстатического постижения, несут в себе прямые предпосылки ассимиляции христианского мировоззрения в античной среде. Неоплатонизм, с одной стороны, готовит философскую основу катафатического теоцентризма, с другой - провозглашает иррациональную, трансфинитивную, надкогнитивную, сверхдискурсивную природу Абсолюта, создавая почву для выхода за рамки рационально-рефлексивной метафизики через обращение к мистическим формам философии апофатического толка.

Еще более определяющую роль играет мистика в средневековом философском контексте. Как реакция на крайнюю абсолютизацию рационального в формировании представлений о боготворимом мире возникают мистические учения в период позднего средневековья. Первая волна такой реакции - это учение Бернара Клервосского. Непосредственное обращение к созерцательной практике представителей умеренного мистицизма XII ст., обогащает схоластические догматы христианства идеями тринитарной диалектики как формы богопознания. Отличие мистики Бернара от неоплатонической трактовки экстатического акта как устремленности духовных сил человека на снисхождение Благодати, выразилось в оформлении идеи стадиальности пути совершенствования человека. 
ISSN 2227-7242. Антропологічні виміри філософських досліджень. 2012. Вип. 1.

Вторая наиболее сильная линия философской мистики не только в средневековье, но и практически во всей истории европейской философии представлена школой немецкой мистики во главе с Мастером Экхартом. Мистическое учение Мастера и его последователей имело для развития европейской философии непреходящее значение для формирования новых ракурсов философского дискурса, представленных как:

- парадоксальность как методологическая основа антиномичности философского мышления, позволяющего охватить сознанием то, что не поддается рациональному, но допускается интуитивно;

- эквивокационность как сверхонтологический принцип абсолютной бытийственности;

- универсально-целостная сущность онтологического всеединства как креативный принцип вечного становления;

- вневременная основа формирования динамической субстанциональности как принципа тринитарного свершения;

- онтологический и гносеологический апофатизм как основа мистической диалектики;

- онтологически обоснованная консубстанциональность человеческого и Божественного;

- антропологическая акцентуация метафизики, противопоставляющая антропоцентричности - антропософский универсализм, выразившийся в трансцендентно-имманентном единстве самоценной сущности бытия человека;

- психологизация гносео-аксеологической компоненты метафизического мышления;

- сверхконфессиональность как мировоззренческая основа универсалистской религиозности.

На основе учения немецких средневековых мистиков вырастает идея протестантизма, а экзистенциальный аспект, привнесенный в средневековую схоластику, зарождает идеи, которые получат развитие в философии неклассического периода.

Своеобразным проявлением мистической линии в западноевропейском историко-философском пространстве является ренессансный неоплатонизм, представленный творчеством
Николы из Кузы, Якоба Беме, Валентина Вайгеля, Себастьяна Франка и другими. В этой связи А. Лосев отмечает значение мистики для эпохи Возрождения: «Прогрессивная роль мистики в мировоззрении ренессансных мыслителей проявилась в разрушении ортодоксальносхоластической картины мира и схоластических методов мышления» [3].

Особенность проявления мистического начала в их представлениях выразилась через совмещение с пантеизмом, гилозоизмом и деизмом ренессансной культуры гуманизма. В результате объединения в их учении апофатического и эферетического подходов с натурфилософскими взглядами формируются протонаучные идеи Нового времени. Мистицизм этого периода нашел выражение в следующих положениях:

- идея совпадение сущности человеческого и Божественного через концепт христологии;

- диалектика имманентного мира и трансцендентного Бога, в которой апофатика применяется в рамках чувственного познания и математических измерений;

- акт познания не ограничивается рефлексией, а понимается как единоактовость богоуподобления через субъект-объектное единение;

- бытие наделяется характеристикой целостности, в которой абсолютный максимум Бога включает в себя мир как свою относительную противоположность (минимум).

В отличие от средневекового мистицизма, ренессансные мистики искали Бога не только в душе, но и в природе. Так, философская мистика ренессансного неоплатонизма формирует протонаучные взгляды в виде разработки проблемы возможностей и природы познания и мышления.

Следует отметить, что и средневековая, и ренессансная мистическая, представленная, прежде всего, немецкой философией, традиции формируют условия становления и развития немецкого идеализма, романтизма и, как следствие, - неклассической философии с характерными для нее иррациональностью, экзистенциальностью, психологизмом и волюнтаризмом. 
ISSN 2227-7242. Антропологічні виміри філософських досліджень. 2012. Вип. 1.

Таким образом, в становлении и развитии европейской истории философии мистические учения, хотя и не доминировали в логикорефлексивном пространстве философского поля, но играли значимую роль в формировании концептуальных парадигмальных изменений. Обобщив проявления философской мистики в рефлексивном поле западноевропейской философии, следует отметить ее общие особенности:

- мистическая проблематика находит, как правило, свое выражение через практическую сферу, представленную как индивидуальные или обще-моральные установки духовного совершенствования личности;

- философская мистика проявляется в рамках философских представлений, понятий и категорий своего времени, подобно конфессиональной мистики в рамках культов той или иной религии;

- философская мистика, в отличие от других форм визионерской мистики, всегда представлена в виде текста, тогда как описание самого мистического опыта остается за его пределами. Таким образом, философская мистика - это не столько выражение мистического опыта, сколько форма его рефлексии в виде системной рационализации, то есть, это философская система, опирающаяся на мистический опыт;

- философская мистика не выражает адекватное содержание мистического опыта в дискурсивных формах, в силу чего, несет в себе потенциал для интерпретаций и толкований, то есть расширения смыслов;

- философская мистика, с одной стороны, всегда трансцендирование субъективности (преодоление самости в слиянии с абсолютом), с другой - всегда субъективный и неповторимый опыт. Именно эта дуальность несет в себе возможность выйти за границы возможного, осмысленного, известного, содержательно расширив предметное поле философии.

Благодаря этим качествам роль мистики в развитии истории философии - эвристична, то есть мистика выступает формой провокации нового вопрошания и нового типа философствования как формы ответа на это вопрошание.

Вечное вопрошание о смысле в самых глубинах бытия философии - откликается эхом абсолютной свободы в царстве чистого духа, в преддверии которого будет всегда стоять, но никогда не решится войти философия, ибо ограничена системой рационально-логического теоретизирования. И только мистика имеет право входа в царство чистого духа, но цена этому - утрата философии.

\section{СПИСОК ИСПОЛЬЗОВАННЫХ ИСТОЧНИКОВ}

1. Философский энциклопедический словарь. М. : ИНФРА-М, 1998. - 576 с.

2. Гучинская, Н. О. Мистическое богословие Мастера Экхарта / Н. О. Гучинская // Начало. 1999. - № 8. - C. 27-38.

3. Лосев, А. Ф. Эстетика возрождения / А. Ф. Лосев. - М. : Мысль, 1978. - 623 с.

Поступила в редколлегию 12.03.2012.

Принята в печать 15.03.2012. 